\title{
Alterations in insulin signalling pathway induced by prolonged insulin treatment of 3T3-L1 adipocytes
}

\author{
J.-M. Ricort, J.-F. Tanti, E. Van Obberghen, Y. Le Marchand-Brustel \\ Institut National de la Santé et de la Recherche Médicale, INSERM U145, Faculté de Médecine, Nice, France
}

\begin{abstract}
Summary Insulin-induced glucose transport stimulation, which results from the translocation of glucose transporter 4 (GLUT 4)-containing vesicles, is completely blocked after prolonged insulin treatment of 3T3-L1 adipocytes. Since GLUT 4 expression was reduced by only $30 \%$, we looked at the insulin signalling pathway in this insulin-resistant model. Insulininduced tyrosine phosphorylation of the major insulin receptor substrate IRS 1 was reduced by $50 \pm 7 \%$, while its expression was decreased by $70 \pm 4 \%$. When cells were treated with wortmannin (a PI3-kinase inhibitor) together with insulin, the expression of IRS 1 diminished to a much lower extent. Associated with the decrease in IRS 1 expression and phosphorylation, the activation by insulin of anti-
\end{abstract}

phosphotyrosine immunoprecipitable PI3-kinase activity and of $\mathrm{p} 44^{\mathrm{mapk}}$ and $\mathrm{p} 42^{\mathrm{mapk}}$ activities was altered. However, the expression of these proteins was normal and $\mathrm{p} 44^{\mathrm{mapk}}$ activity remained responsive to the tumour promoter TPA. Those results indicate that prolonged insulin treatment of 3T3-L1 adipocytes induces an insulin-resistant state with a reduced ability of insulin to stimulate the PI3-kinase and the MAP-kinases and a blockade of glucose transporter translocation. [Diabetologia (1995) 38: 1148-1156]

Key words Insulin signalling, MAP-kinase, PI3-kinase, IRS 1, GLUT 4 translocation, insulin resistance, wortmannin.
In adipose tissue and skeletal muscle, insulin stimulation of glucose transport results from the translocation of vesicles containing the glucose transporters GLUT 4 from an intracellular compartment to the plasma membrane [1-3]. However, the molecular events between the activation of the insulin receptor tyrosine kinase and the translocation of GLUT 4 re-

Received: 28 February 1995 and in revised form: 4 May 1995

Corresponding author: Dr. J.M. Ricort, INSERM U 145, Faculté de Médecine, Avenue de Valombrose, F-06107 Nice Cedex 02, France

Abbreviations: GLUT, Glucose transporter; TPA, tumour promoter; MAPK, mitogen-activated protein kinase; IRS, insulin receptor substrate; $\mathrm{SH} 2$, src homology 2; GRB, GRB: Growth factor Receptor bound protein; PVDF, polyvinyliden difluoride; HDM/LDM, high density/low density microsomes; MBP, myelin basic protein; DMEM, Dulbecco's modified Eagle's medium; PMSF, phenylmethanesulphonyl fluoride; PI3-kinase: phosphatidylinositol 3'-kinase main ill-defined. Some insight into the understanding of insulin signalling has been obtained with the cloning of the major insulin receptor substrate IRS 1 (insulin receptor substrate 1) [4]. In most cells, this $160-185 \mathrm{kDa}$ protein is rapidly tyrosine-phosphorylated after insulin exposure, and then docks several proteins containing src-homology 2 ( $\mathrm{SH} 2$ ) domains such as the phosphotyrosine phosphatase Syp, Nck, the p85 subunit of the phosphatidylinositol 3'-kinase (PI3-kinase) and GRB 2 [5]. GRB 2 couples the Ras guanine-nucleotide releasing factor Sos to IRS 1 and then links the insulin receptor to the Ras/mitogen-activated protein kinases (MAPK) signalling pathway $[6,7]$. A whole set of data suggests that IRS 1 is essential for some, if not all, of insulin's biological responses $[5,8]$. Indeed, when IRS 1 levels are reduced by overexpression of an antisense cDNA, insulin mitogenic response is blocked [9]. In a similar fashion, serine/threonine phosphorylation of IRS 1 induces a decrease in its insulin-induced tyrosine phosphoryla- 
tion and a blockade in the stimulation of glucose transport and PI3-kinase activity [10]. However, the possible implication of the different molecules of the cascade following IRS 1 phosphorylation in the regulation of insulin-induced glucose transport remains unknown.

Insulin resistance for glucose transport can result from various defects including: 1) alterations in insulin receptor functioning, 2) depletion of the GLUT 4 transporter pool and 3) alterations in the post-receptor signalling pathway [11]. An insulin-resistant state due to defects in signal transmission has been obtained following a prolonged insulin treatment of 3T3-L1 adipocytes [12]. Indeed, this treatment, which did not modify the insulin receptor and the GLUT 4 amounts, totally prevented the GLUT 4 translocation in response to acute insulin stimulation [12], and induced a decrease in IRS 1 expression due to proteolysis $[13,14]$.

In the present work, we have taken advantage of this model to investigate whether the decrease in IRS 1 amount was associated with defects in PI3-kinase and MAPK activation, and whether such alterations could be correlated with the lack of insulin-induced GLUT 4 translocation.

\section{Materials and methods}

Antibodies. Antibodies to GLUT 4 and GLUT 1 were obtained from rabbits injected with peptides corresponding to the 12 or 14 amino acids of the C-terminus of GLUT 4 and GLUT 1, respectively [15], and were used at $1 / 500$ and 1/200 dilution for immunoblotting experiments. Antibodies to IRS 1, kindly provided by Dr. C.R.Kahn (Boston, Mass., USA) were raised in a rabbit using a synthetic peptide derived from the sequence $489-507$ of IRS 1 [16]. Antibodies to $\mathrm{p} 44^{\mathrm{mapk}}$ and $\mathrm{p} 42^{\mathrm{mapk}}$ were obtained by immunizing rabbits against a peptide corresponding to the C-terminus of each protein [17]. Antibodies to p85 PI3-kinase and antibodies to phosphotyrosine were from UBI (Lake Placid, N. Y., USA) or obtained in our laboratory after injection of a rabbit with phosphotyrosine coupled to bovine immunoglobulins.

Cell culture. The 3T3-L1 fibroblasts were cultured in Dulbecco's modified Eagle's medium (DMEM) $10 \%$ fetal calf serum and induced to differentiate into adipocytes as described [18]. These 3T3-L1 adipocytes were used between 8 and 12 days after initiation of differentiation, when more than $95 \%$ of the cells exhibited the adipocyte phenotype. Prolonged insulin treatment of 3T3-L1 adipocytes was performed as described [12] with minor modifications. Cells were incubated for different periods of time in DMEM $/ 10 \%$ fetal calf serum with $100 \mathrm{nmol} / \mathrm{l}$ insulin. Cells were then washed three times at $37^{\circ} \mathrm{C}$ with Krebs-Ringer-Mes buffer (in mmol/l: $136 \mathrm{NaCl}, 4.7 \mathrm{KCl}, 1.25 \mathrm{CaCl}_{2}, 1.25 \mathrm{MgSO}_{4}, 10 \mathrm{Mes}$, pH 6.0). Cells were then incubated for $1 \mathrm{~h}$ in the same buffer supplemented with $25 \mathrm{mmol} / 1 \mathrm{D}$-glucose and $0.2 \%$ (w/v) bovine serum albumin (BSA) and washed three times with the same buffer, then three times with phosphate buffered saline (PBS)/BSA. Cells were incubated in PBS/BSA for 20-30 min before being stimulated. Control cells were submitted to the same washing protocol as the chronically insulin-treated cells.
Deoxyglucose uptake measurement. The 3T3-L1 adipocytes were incubated for $10 \mathrm{~min}$ in $\mathrm{PBS} / \mathrm{BSA}$ with or without $100 \mathrm{nmol} / \mathrm{l}$ insulin. Then, 2-deoxy-[1- $\left.{ }^{3} \mathrm{H}\right] \mathrm{D}$-glucose $(100 \mu \mathrm{mol} /$ $1,0.1 \mu \mathrm{Ci}$ ) was added for $5 \mathrm{~min}$. Cells were washed twice with ice-cold PBS, solubilized in 0.1 normal $\mathrm{NaOH}$ and their associated radioactivity was determined.

Subcellular fractionation of 3T3-L1 adipocytes and GLUT 4 immunodetection. The 3T3-L1 adipocytes (cells from two 150$\mathrm{mm}$ dishes) were incubated with or without $100 \mathrm{nmol} / 1$ insulin for $15 \mathrm{~min}$ at $37^{\circ} \mathrm{C}$ in $10 \mathrm{ml}$ of PBS/BSA. Cells were washed twice with PBS, scraped in $10 \mathrm{ml}$ of TES buffer (in $\mathrm{mmol} / \mathrm{l}$ : 20 Tris $\mathrm{pH} 7.4,1$ EDTA, 250 sucrose, $\mathrm{pH} 7.4$, aprotinin $100 \mathrm{U} /$ $\mathrm{ml}$ and $1 \mathrm{mmol} / \mathrm{l} \mathrm{PMSF}$ ) and homogenized with 15 strokes in a Thomas Potter (Type C Philadelphia, PA, USA). Homogenates were centrifuged at $16,000 \mathrm{~g}$ for $20 \mathrm{~min}$. The supernatant was centrifuged for $90 \mathrm{~min}$ at $210,000 \mathrm{~g}$ to obtain a pellet referred to as high-density/low-density microsomes (HDM/ LDM). In parallel, the $16,000 \mathrm{~g}$ pellet was rehomogenized in $4 \mathrm{ml}$ of TES buffer, overlaid on a sucrose cushion $(38 \% \mathrm{w} / \mathrm{v}$, in Tris/EDTA buffer) and centrifuged for $60 \mathrm{~min}$ at $100,000 \mathrm{~g}$. The plasma membranes between the two layers were collected, diluted in Tris buffer, and pelleted by centrifugation for $75 \mathrm{~min}$ at $210,000 \mathrm{~g}$. Pellets of each fraction were resuspended in 50 $100 \mu \mathrm{l}$ TES and protein content determined by the Bio-Rad assay (Richmond, CA, USA) with BSA as standard.

Proteins from the different fractions $(50-100 \mu \mathrm{g})$ were solubilized in Laemmli buffer ( $3 \%$ SDS, $70 \mathrm{mmol} / 1$ Tris, $11 \%$ glycerol) containing bromophenol blue $(0.05 \%)$ and 2 -mercaptoethanol $(700 \mathrm{mmol} / \mathrm{l})$ and separated by SDS/PAGE with a $10 \%$ resolving gel [19]. Proteins were transferred to a polyvinyliden difluoride (PVDF) sheet. The efficiency of the transfer and the similarity in the protein amounts in the different lanes were controlled by coloration with Ponceau Red. The sheet was incubated with blocking buffer (PBS/5\% fat skimmed dry milk) for $2 \mathrm{~h}$ at room temperature. The sheet was then incubated overnight at $4^{\circ} \mathrm{C}$ with the antibodies to GLUT 4. After three washes (10 min each) in PBS containing $1 \%$ Nonidet P40 (Fluko, Bucks, Switzerland), the sheet was incubated for $1 \mathrm{~h}$ at room temperature with $\left[{ }^{125} \mathrm{I}\right]$ protein A $\left(5 \times 10^{5} \mathrm{cpm} / \mathrm{ml}\right.$ blocking buffer $)$ and washed as above. Blots were submitted to autoradiography. Quantification was performed by counting the radioactivity associated with the bands and/or by scanning (Hoefer Scientific Instrument San Francisco, CA, USA).

Immunodetection of phosphotyrosine-containing proteins and other proteins (IRS 1, $p 85$ PI3-kinase, 44 $^{\text {mapk }}$ ). Following prolonged treatment with insulin, 3T3-L1 adipocytes were stimulated for $7 \mathrm{~min}$ with or without $100 \mathrm{nmol} / 1$ insulin. Cells were then washed twice with PBS and solubilized for $40 \mathrm{~min}$ at $4{ }^{\circ} \mathrm{C}$ in $1 \mathrm{ml}$ of buffer $\mathrm{A}$ (in mmol/l: 20 Tris $\mathrm{pH} \mathrm{7.4,137} \mathrm{NaCl}$, $100 \mathrm{NaF}, 10 \mathrm{EDTA}, 2 \mathrm{Na}_{3} \mathrm{VO}_{4}, 10$ pyrophosphate, $1 \mathrm{PMSF}$, $1 \%$ Nonidet $\mathrm{P} 40,100 \mathrm{U} / \mathrm{ml}$ aprotinin). Then, cell lysates $(50-$ $100 \mu \mathrm{g}$ proteins) were treated with Laemmli buffer and separated on SDS/PAGE with a $7.5 \%$ polyacrylamide resolving gel. Proteins were transferred to PVDF membranes. Membranes were saturated with PBS/ $5 \%$ BSA for $2 \mathrm{~h}$ at room temperature and incubated overnight with antibodies to phosphotyrosine $(1 \mu \mathrm{g} / \mathrm{ml}$ saturation buffer), IRS 1 (1/200 in saturation buffer), p44 $4^{\text {mapk }}$ (1/100 in saturation buffer), p85 PI3-kinase (1/1000 in saturation buffer). Membranes were washed as described above. When antibodies to phosphotyrosine were used, a further incubation was performed for $1 \mathrm{~h}$ at room temperature with rabbit anti-mouse immunoglobulins. Finally, sheets were incubated with $\left[{ }^{125} \mathrm{I}\right]$ protein $\mathrm{A}$ and washed as described above. 
Determination of PI3-kinase activity. Control or chronically insulin-treated 3T3-L1 adipocytes were stimulated or not with $100 \mathrm{nmol} / \mathrm{l}$ insulin and solubilized in $1 \mathrm{ml}$ buffer $A$ for $40 \mathrm{~min}$ at $4^{\circ} \mathrm{C}$. Lysates were centrifuged for $10 \mathrm{~min}$ at $13,000 \mathrm{~g}$. Supernatants were incubated for $90 \mathrm{~min}$ at $4^{\circ} \mathrm{C}$ with antibodies to phosphotyrosine or to the PI3-kinase $85 \mathrm{kDa}$ subunit coupled to protein A sepharose beads. Thereafter, immune pellets were washed twice with each of the three following buffers: (a) PBS containing $1 \%$ Nonidet p40 and $200 \mu \mathrm{mol} / 1 \mathrm{Na}_{3} \mathrm{VO}_{4}$; (b) $100 \mathrm{mmol} / 1$ Tris $\mathrm{pH} 7.4,0.5 \mathrm{~mol} / 1 \mathrm{LiCl}, 200 \mu \mathrm{mol} / 1 \mathrm{Na}_{3} \mathrm{VO}_{4}$, and (c) $10 \mathrm{mmol} / 1$ Tris $\mathrm{pH} 7.4,100 \mathrm{mmol} / \mathrm{l} \mathrm{NaCl}, 1 \mathrm{mmol} / \mathrm{l}$ EDTA, $200 \mu \mathrm{mol} / 1 \mathrm{Na}_{3} \mathrm{VO}_{4}$. PI3-kinase activity was measured on the immune pellets as previously described [20,21].

Measurement of $p 42^{m a p k}$ and $p 44^{m a p k}$ activities. Lysates obtained from cells treated as described above were used to measure MAPK activities. Phosphorylated $\mathrm{p} 42^{\text {mapk }}$ was visualized by its characteristic retardation in electrophoretic mobility [22]. The p44 $4^{\text {mapk }}$ activity was measured by incubating cell lysates with antibodies to $\mathrm{p}^{4} 4^{\mathrm{mapk}}$ coupled to protein $\mathrm{A}$ sepharose beads for $90 \mathrm{~min}$ at $4^{\circ} \mathrm{C}$. Immune pellets were washed three times with homogenization buffer and twice with HNT buffer $(30 \mathrm{mmol} / 1$ Hepes $\mathrm{pH} 7.4,30 \mathrm{mmol} / 1 \mathrm{NaCl}, 0.1 \%$ Triton $\mathrm{X}-100$ ) containing $200 \mu \mathrm{mol} / 1 \mathrm{Na}_{3} \mathrm{VO}_{4}$. Pellets were resuspended in $50 \mu \mathrm{l}$ of HNT buffer and p44 $4^{\text {mapk }}$ activity was measured by addition of $10 \mu \mathrm{l}$ of a solution containing $30 \mathrm{mmol} / \mathrm{l}$ Hepes, $30 \mathrm{mmol} / 1 \mathrm{NaCl}, 0.1 \%$ Triton $\mathrm{X}-100,30 \mu \mathrm{mol} / 1\left[\gamma-{ }^{32} \mathrm{P}\right]$ ATP $(10 \mu \mathrm{Ci}), 6 \mathrm{mmol} / \mathrm{l} \mathrm{DTT}, 60 \mathrm{mmol} / \mathrm{l}\left(\mathrm{CH}_{3} \mathrm{COO}\right)_{2} \mathrm{Mg}$, $1 \mathrm{mg} / \mathrm{ml}$ myelin basic protein (MBP). After $15 \mathrm{~min}$, samples were spotted on phosphocellulose paper and immersed in a bath of $1 \%$ orthophosphoric acid. Papers were washed three times for $10-15 \mathrm{~min}$ each and dried before quantification by Cerenkov counting [17].

\section{Results}

Glucose transport and glucose transporter translocation in chronically insulin-treated 3T3-L1 adipocytes. Previous studies have shown that prolonged insulintreatment of 3T3-L1 adipocytes induces an inability of the cells to recruit GLUT 4 to the cell surface following an acute insulin stimulation [12]. Since in our 3T3-L1 adipocytes, the previously published conditions [12] profoundly decreased GLUT 4 expression, insulin treatment was slightly modified. We first verified that the cells became insulin-resistant for glucose transport. As shown in Table 1, in control cells, acute insulin treatment increased deoxyglucose transport eightfold. By contrast, after $10 \mathrm{~h}$ of chronic-insulin treatment, basal transport was five times higher than in control cells but did not increase further upon an acute insulin stimulation.

The total amount of GLUT 1 and GLUT 4 proteins in cell homogenates was quantified by immunoblotting. It should be noted that insulin treatment did not modify the total cellular protein content (data not shown) and thus identical protein amounts were analysed, which corresponded to identical cell numbers. As shown in Table 1, GLUT 1 expression was increased by two fold while GLUT 4 amount decreased by $30 \%$ following prolonged insulin treat-
Table 1. Effect of prolonged insulin treatment on insulin-induced glucose transport and glucose transporter expression

\begin{tabular}{lcc}
\hline & Control cells & Treated cells \\
\hline Deoxyglucose uptake & & \\
Basal & $0.28 \pm 0.02$ & $1.51 \pm 0.29$ \\
Insulin & $2.30 \pm 0.70$ & $1.81 \pm 0.35$ \\
Glucose transporters & $\cdot$ & \\
GLUT 1 & 100 & $190 \pm 28$ \\
GLUT 4 & 100 & $67 \pm 7$ \\
\hline
\end{tabular}

Control or chronically insulin-treated 3T3-L1 adipocytes, were stimulated or not for $15 \mathrm{~min}$ with $100 \mathrm{nmol} / \mathrm{l}$ insulin before measuring 2-deoxyglucose (DOG) uptake $(0.1 \mathrm{mmol} / 1$, $0.1 \mu \mathrm{Ci} / a s s a y)$ during a 5-min period as described in Methods. Values are expressed as nmol of DOG incorporated/assay and are the means \pm SEM of three-four experiments. Glucose transporters were quantified as follows: cellular homogenates (100 $\mu \mathrm{g}$ of proteins) were subjected to SDS/PAGE; proteins were transferred to PVDF sheets and immunodetected with antibodies to GLUT 4 or GLUT 1 as described in Methods. Results are the means \pm SEM of three-four different experiments and are expressed as a percentage of the values obtained in control cells

ment. To investigate whether the alteration in glucose transport stimulation was due to an alteration in GLUT 4 translocation, control and chronically insulin-treated cells were stimulated or not for $15 \mathrm{~min}$ with $100 \mathrm{nmol} / \mathrm{l}$ insulin and submitted to subcellular fractionation. Following electrophoresis, proteins were transferred to PVDF membrane and GLUT 4 molecules were identified using specific antibodies and $\left[{ }^{125} \mathrm{I}\right]$-labelled protein A. A typical autoradiogram is shown in Figure 1 and the quantification of three experiments is presented in Table 2 . In control and treated cells, most of the GLUT 4 transporters were located in HDM/LDM in the absence of insulin. After insulin stimulation of control cells, the

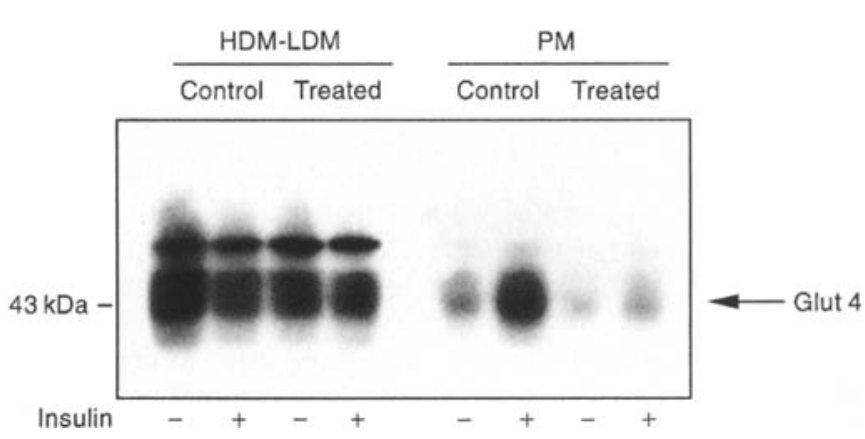

Fig.1. Effect of prolonged insulin-treatment on insulin-induced GLUT 4 translocation. Control and chronically insulintreated 3T3-L1 adipocytes were stimulated for $15 \mathrm{~min}$ with or without $100 \mathrm{nmol} / 1$ insulin. Cells were fractionated in high density/low density microsomes (HDM/LDM) and plasma membranes (PM) as described in Methods. Proteins from each fraction were separated by SDS-PAGE, transferred to PVDF sheets and incubated with antibody to GLUT 4 and $\left[{ }^{125} \mathrm{I}\right]$-protein A. Sheets were then submitted to autoradiography. A typical autoradiogram is shown 
Table 2. Effect of prolonged insulin treatment on insulin-induced GLUT 4 translocation

\begin{tabular}{lcc}
\hline & Control cells & Treated cells \\
\hline GLUT 4 in PM fraction & 1 & \\
Basal & $2.39 \pm 0.49^{\mathrm{a}}$ & $0.68 \pm 0.15$ \\
Insulin & $0.98 \pm 0.17$ \\
GLUT 4 in HDM/LDM fraction & \\
Basal & 1 & $0.67 \pm 0.06$ \\
Insulin & $0.60 \pm 0.01^{\mathrm{a}}$ & $0.54 \pm 0.05$ \\
\hline
\end{tabular}

Control or chronically insulin-treated 3T3-L1 adipocytes were stimulated or not for $15 \mathrm{~min}$ with $100 \mathrm{nmol} / \mathrm{l}$ insulin before subcellular fractionation into plasma membranes (PM) and high/ low density microsomes (HDM/LDM) as described in Methods. Glucose transporters were quantified in each fraction by immunodetection. Results are the means \pm SEM of three different experiments. To allow comparison amongst experiments, the amounts of GLUT 4 were expressed relative to the amount of transporters present in control basal conditions.

${ }^{a}$ Insulin effect was significant with $p<0.05$

amount of GLUT 4 decreased by $40 \%$ in the HDM/ LDM and increased 2.4-fold in plasma membranes. In contrast, no significant change in the subcellular distribution of GLUT 4 occurred in treated cells. Thus, as previously reported [12], after prolonged insulin treatment, 3T3-L1 adipocytes became insulinresistant for glucose transport and GLUT 4 translocation indicating that the signalling mechanism leading to translocation was altered.

Insulin receptor autophosphorylation and IRS 1 phosphorylation. To investigate which steps in insulin signalling could be altered after prolonged exposure to the hormone, we looked for the ability of insulin to stimulate protein tyrosine phosphorylation. Control or insulin-treated 3T3-L1 adipocytes were acutely exposed or not to insulin, homogenized and cellular proteins were separated on SDS/PAGE, transferred to PVDF membranes and immunoblotted with antibodies to phosphotyrosine (Fig. 2A) or IRS 1 (Fig. 2B). As shown in Figure 2A, in control cells, insulin stimulated the tyrosine phosphorylation of two proteins, one with a $\mathrm{M}_{\mathrm{r}}$ of $95 \mathrm{k}$ corresponding to the insulin receptor $\beta$-subunit, and another one with a $\mathrm{M}_{\mathrm{r}}$ of $160 \mathrm{k}$, identified as IRS 1 with a specific antibody (Fig. 2B). In chronically insulin-treated cells, the phosphorylation of IRS 1 was decreased by $50 \pm 7 \%$ (mean \pm SEM of six experiments) in response to an acute insulin stimulation. IRS 1 expression, measured using an antibody to IRS 1, (Fig. 2B), was decreased by $70 \pm 4 \%$ (mean \pm SEM of six determinations) in chronically insulin-treated cells compared to control cells.

Effect of prolonged insulin treatment on PI3-kinase activity. Since activation of PI3-kinase results from its binding to phosphorylated IRS 1 , we have investigated whether the decreased IRS 1 amount and phos-

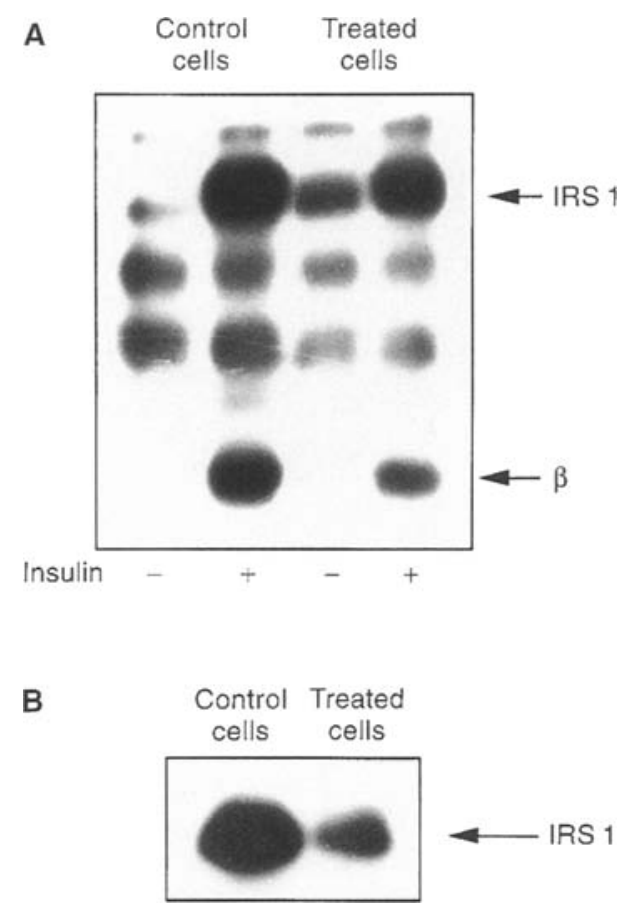

Fig. 2 A, B. Effect of prolonged insulin-treatment on insulininduced tyrosine phosphorylation of proteins. Control and chronically insulin-treated 3T3-L1 adipocytes were treated with or without $100 \mathrm{nmol} / 1$ insulin for $7 \mathrm{~min}$. Proteins were solubilized in buffer containing phosphatase inhibitors and subjected to SDS/PAGE. The proteins were transferred to PVDF sheets, then incubated with antibodies to phosphotyrosine (panel A) or to IRS 1 (panel B) as described in Methods. The sheets were then submitted to autoradiography. Typical autoradiograms are presented. Quantification of five different experiments indicated that, after prolonged insulin treatment, insulin-induced tyrosine phosphorylation of its receptor and IRS 1 was decreased by $40 \%$, while the IRS 1 amount was reduced by $70 \pm 5 \%$. $\beta$ refers to the insulin receptor beta-subunit

phorylation modified PI3-kinase activation. Control and 3T3-L1 adipocytes treated with insulin for $10 \mathrm{~h}$ were acutely stimulated with insulin for different periods of time before measuring PI3-kinase activity in immunoprecipitates obtained with antibodies to phosphotyrosine. As shown in Figure 3, in control cells, the insulin stimulation of PI3-kinase activity was rapid, with maximal effect (60-fold over basal) obtained after 2 min of stimulation, then this activity decreased rapidly and reached a plateau within $15 \mathrm{~min}$. In cells chronically treated with insulin for $10 \mathrm{~h}$, basal PI3-kinase activity was slightly increased (two fold over untreated cells) and the time course of PI3kinase activation after an acute insulin stimulation was similar to control cells, but maximal activity was reduced by $70 \%$. This inhibition was not due to a change in the total amount of the enzyme detected by immunoblotting (Fig.3, inset).

Effect of prolonged insulin treatment on $p 44^{\text {mapk }}$ and $p 42^{\text {mapk }}$ activities. Insulin-induced IRS 1-GRB2/Sos complex formation is thought to be partly involved 


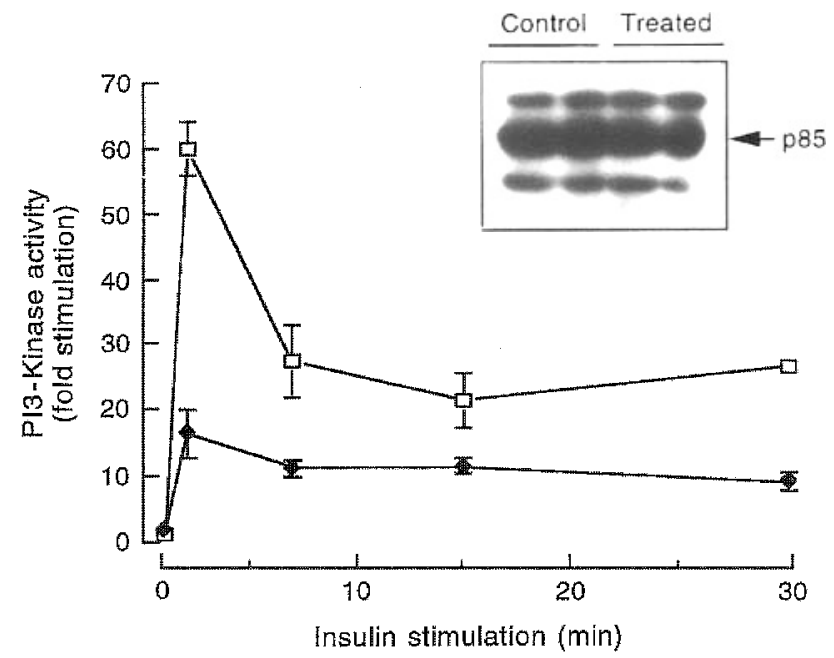

Fig.3. Insulin stimulation of PI3-kinase activity in control and chronically insulin-treated 3T3-L1 adipocytes. Control cells $(\square)$ and chronically insulin-treated cells for $10 \mathrm{~h} \mathrm{(} \bullet$ ) were incubated in absence or presence of $100 \mathrm{nmol} / \mathrm{l}$ insulin for 2 30 min before homogenization and immunoprecipitation with antibodies to phosphotyrosine. PI3-kinase assay was performed on the immune pellet as described in Methods. Quantification of the PI-3-P product was performed by scintillation counting. To allow for comparison amongst experiments, the activities were expressed relative to the activity measured in control cells incubated in the basal condition. In treated cells, the basal activity, was $1.98 \pm 0.45$, mean \pm SEM of three experiments. In the inset is shown the immunodetection of $\mathrm{p} 85$ PI3kinase subunit. Identical amounts of proteins from control and treated cells were analysed as described in Methods

in coupling the insulin receptor kinase to the Ras signalling pathway leading to the MAPK activation. Thus, we have investigated whether changes in IRS 1 phosphorylation and/or amount, induced by prolonged insulin treatment, could modify MAPK activation. Cells were stimulated with insulin and solubilized as described above. Following immunoprecipitation with a specific antibody, p44 ${ }^{\text {mapk }}$ activity was determined with MBP as substrate. As shown in Figure 4 , in control cells, p44 $4^{\mathrm{mapk}}$ activity was increased by threefold within $7 \mathrm{~min}$ of insulin stimulation and returned to basal values within $30 \mathrm{~min}$. After $10 \mathrm{~h}$ of chronic-insulin treatment, basal activity was unchanged but the insulin-induced $\mathrm{p} 44^{\mathrm{mapk}}$ activity was markedly blunted with only a slight stimulation remaining within $7 \mathrm{~min}$. This lack of activation was not due to a change in $\mathrm{p}^{44^{\mathrm{mapk}}}$ expression as determined by immunoblotting experiment (Fig.4, inset). Further, tumour promotor (TPA) $(1 \mu \mathrm{mol} / \mathrm{l})$ was as efficient in activating $\mathrm{p}^{4} 4^{\mathrm{mapk}}$ activity in control cells $(2.92 \pm 0.05$-fold $)$ as in chronically insulin-treated 3T3-L1 adipocytes ( $2.57 \pm 0.22$-fold).

To detect activation of $\mathrm{p} 42^{\mathrm{mapk}}$, a gel shift assay was used since the phosphorylated form of the kinase has a slower electrophoretic mobility than the non-phosphorylated form [22]. Cell lysates were submitted to SDS/PAGE and p42 $2^{\text {mapk }}$ detected by im-

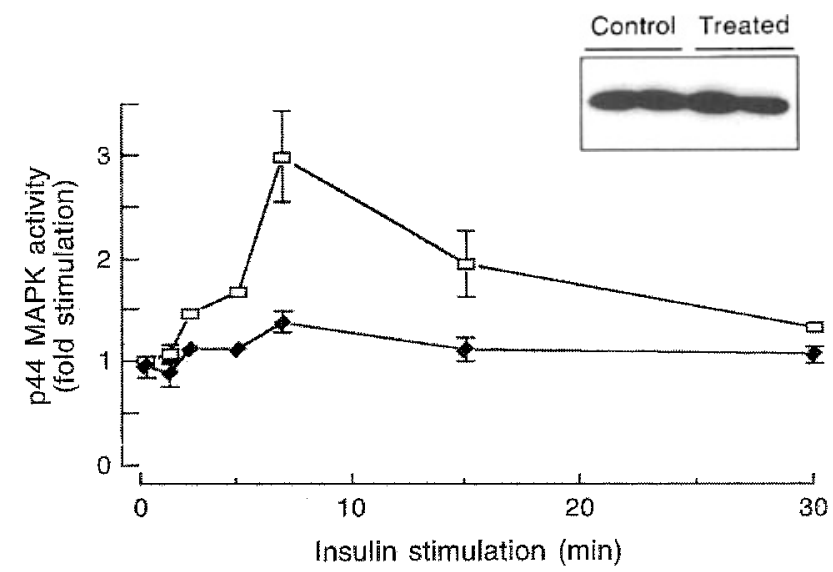

Fig.4. Insulin stimulation of $\mathrm{p}^{44^{\mathrm{mapk}}}$ activity in control and chronically insulin-treated 3T3-L1 adipocytes. Control cells $(\square)$ and chronically insulin-treated cells ( $\bullet$ ) were incubated for $10 \mathrm{~h}$ in absence or in presence of $100 \mathrm{nmol} / \mathrm{l}$ insulin for 2-30 min before homogenization and immunoprecipitation with antibodies to $\mathrm{p} 44^{\text {mapk }}$. $\mathrm{p} 44^{\text {mapk }}$ activity was measured by phosphorylation of MBP as described in Methods. To allow for comparison amongst experiments, the activities were expressed relative to the activity measured in control cells incubated in the basal condition. In treated cells, the basal activity was $0.95 \pm 0.11$, mean $\pm \mathrm{SEM}$ of three experiments. In the inset is shown the immunodetection of $\mathrm{p}^{44^{\mathrm{mapk}}}$. Identical amounts of proteins from control and treated cells were analysed as described in Methods

munoblotting. Acute insulin stimulation induced a retardation in the electrophoretic mobility of the kinase due to its phosphorylation in control but not in chronically insulin-treated cells (Fig.5).

To determine whether the defect in the activation of PI3-kinase and p44 ${ }^{\mathrm{mapk}}$ occurred with a similar time course following insulin treatment, 3T3-L1 adipocytes were chronically treated or not with $100 \mathrm{nmol} / \mathrm{l}$ insulin for different periods of time. The cells were washed and PI3-kinase or p44 $4^{\text {mapk }}$ activities were measured after 2 or $7 \mathrm{~min}$ of insulin stimulation, the time corresponding to their respective peak activation. Both PI3-kinase and p44 ${ }^{\text {mapk }}$ activities decreased in parallel when the time of insulin treatment increased from $1 \mathrm{~h}$ to $10 \mathrm{~h}$ (data not shown).

Wortmannin inhibits the insulin-induced decrease in IRS 1 expression. To search for the mechanism of the decrease in IRS 1 expression induced during longterm insulin treatment, we studied the effect of the PI3-kinase inhibitor, wortmannin [23, 24]. In this series of experiments a high concentration of insulin $(500 \mathrm{nmol} / \mathrm{l})$ was used to provoke a profound diminution of IRS 1 and GLUT 4. Indeed, when cells were treated for $5 \mathrm{~h}$ with insulin (500 nmol/1) (Fig.6), a marked degradation of IRS 1 , accompanied by a shift in its molecular weight was observed while the decrease in GLUT 4 was observed only after $24 \mathrm{~h}$. Wortmannin $(1 \mu \mathrm{mol} / 1)$ prevented these insulin ef- 


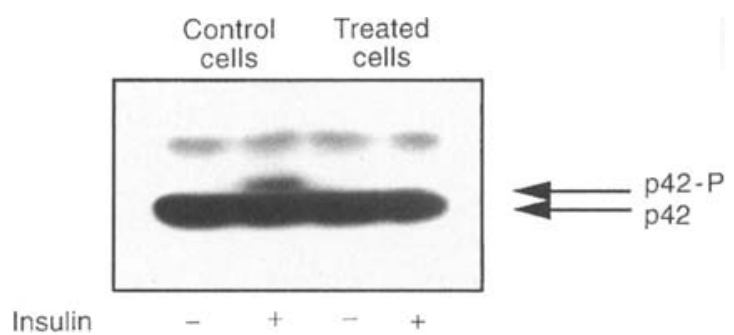

Fig. 5. Effect of prolonged insulin-treatment on $p 42^{\text {mapk }}$ activity. Cells were incubated with or without insulin $(100 \mathrm{nmol} / \mathrm{l})$ for $7 \mathrm{~min}$ and then solubilized. Proteins were separated by SDS-PAGE, transferred to PVDF membranes and immunoblotted with antibody to $\mathrm{p} 42^{\mathrm{mapk}}$ and revealed with $\left[{ }^{125} \mathrm{I}\right]$ protein $\mathrm{A}$. The positions of the phosphorylated form (p42-P) and the unphosphorylated form (p42) of the MAPK are indicated

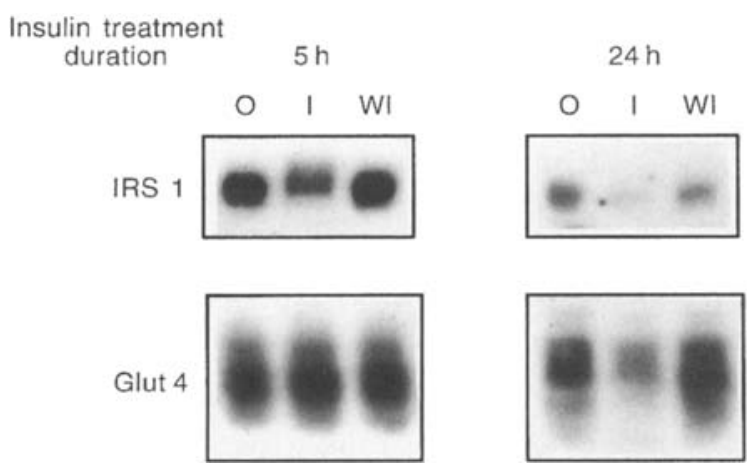

Fig. 6. Wortmannin prevents the insulin-induced decrease in IRS 1 and GLUT 4 expression. 3T3-L1 adipocytes were treated for 5 or $24 \mathrm{~h}$ in absence $(\mathrm{O})$ or in presence of $500 \mathrm{nmol} / \mathrm{l}$ insulin (I, WI) and $1 \mu \mathrm{mol} / \mathrm{l}$ wortmannin (WI) and then washed as described in Methods. Cellular proteins were separated by SDS/PAGE and immunoblotted with antibodies to IRS 1 (top panel) or to GLUT 4 (bottom panel). A typical autoradiogram is shown

fects on IRS 1 and GLUT 4 expression, suggesting that PI3-kinase was involved in these insulin effects.

\section{Discussion}

Previous studies have shown that prolonged treatment of 3T3-L1 adipocytes with insulin leads to an increased basal glucose transport $[12,25,26]$ and to an insulin-resistant state for this transport $[12,26]$. In the previously published studies $[12,25,26]$, the total amount of GLUT 4 was not changed but the GLUT 4 translocation from the internal compartment to the cell surface in response to an acute insulin stimulation was completely blocked [12]. For unknown reasons, the same experimental conditions, i.e. $500 \mathrm{nmol} / \mathrm{l}$ insulin for $24 \mathrm{~h}$, dramatically decreased the total GLUT 4 amount in our 3T3-L1 cell line (Fig.6) and in other studies [27, 28]. As previously described [13], chronic insulin treatment also decreased the IRS 1 content, a decrease which was attributed to an enhancement of IRS 1 degradation
[14]. These effects of insulin on IRS 1 and GLUT 4 expression were blocked by wortmannin, a PI3-kinase inhibitor $[23,24]$, indicating that PI3-kinase is likely to play a role in this process. PI3-kinase is a dual specificity enzyme, with a lipid kinase activity and a serine kinase activity [29]. This serine kinase activity which is able to phosphorylate IRS 1 is also blocked by wortmannin [30,31]. From our results it is not possible to decipher whether the insulin-induced downregulation of IRS 1 results from its serine/threonine phosphorylation or from the increase in lipid kinase activity, but the blockade of IRS 1 and GLUT 4 downregulation by wortmannin indicates that PI3 kinase is involved in this long-term insulin effect.

In the following series of experiments, in which biological insulin responses were measured, we reduced both the length of insulin treatment to $10 \mathrm{~h}$ and the hormone concentration to $100 \mathrm{nmol} / 1$, conditions which induced insulin resistance for glucose uptake and glucose transporter translocation with only a moderate decrease in GLUT 4 expression (Fig.1). We then looked for the defects in the insulin signalling pathway leading to glucose transporter translocation. The amount of IRS 1 was reduced by $40 \%$. It should be noted that chronic-insulin treatment affected protein expression differently, although total protein concentrations were similar in control and treated cells. While it markedly depressed IRS 1 and moderately decreased GLUT 4, it increased GLUT 1 but did not change the two $\mathrm{p} 42$ and $\mathrm{p} 44^{\mathrm{mapk}}$ isoforms or PI3-kinase levels. Tyrosine phosphorylation of the insulin receptor and IRS 1 was reduced by $50 \%$ while the IRS 1 amount was decreased by $70 \%$ suggesting that tyrosine phosphorylation per IRS 1 molecule was increased in this insulin-resistant model. Tyrosine phosphorylated IRS 1 binds and activates PI3-kinase [32,33] and also binds the GRB2Sos complex which is involved in the activation of the Ras/MAPK pathways [5-7]. Thus, a reduction in the tyrosine phosphorylation of IRS 1 might result in alteration in the activation of PI3-kinase and MAPK. Our results indicate that in chronically insulin-treated cells, the activation of both PI3-kinase and MAPKinases was reduced by $70-80 \%$ without a change in the expression of these enzymes. This reduction in activity was more closely correlated to the decrease in IRS 1 amount (70\%) than to its tyrosine phosphorylation (50\%). This could be due to the fact that hyperphosphorylation of IRS 1 occurs on tyrosine residues which are not in canonical sequences involved in the binding of PI3-kinase or GRB2-Sos complex. However, the MAPK cascade can also be initiated by the binding of the GRB2-Sos complex to Shc [34] and Shc has even been suggested to play a more important role than IRS-1 in insulin stimulation of $\mathrm{p} 21^{\text {ras }}$-activation in cells overexpressing insulin receptors $[35,36]$. A reduction in the tyrosine 
phosphorylation and/or in the amount of Shc could also contribute to the defect in MAPK activation.

A key role of IRS 1 in the transmission of insulin effect on glucose transport is supported by a series of observations. First, the IRS 1 amount increases dramatically when 3T3-L1 fibroblasts differentiate into adipocytes. This enhancement in IRS 1 expression parallels the increase in the amount of insulin receptors, the appearance of GLUT 4 expression and the occurrence of an insulin-induced glucose transport [13]. Second, following a treatment of 3T3-L1 adipocytes with okadaic acid, there was a close correlation between the reductions of IRS 1 tyrosine phosphorylation and of the stimulation of glucose transport in response to insulin [10]. Third, in many physiopathologic states linked to insulin resistance, the tyrosine phosphorylation of IRS 1 is reduced [37, 38]. If all those observations argue for a role of IRS 1 in the stimulation of glucose transport, the pathway downstream of IRS 1 remains ill-defined. In this study, we have shown that both the activation of PI3-kinase and MAPK was markedly altered. However, the potential role of these two enzymes in the stimulation of glucose transport is controversial. Indeed, okadaic acid and TPA, which activate MAPK but not PI3-kinase induce glucose transporter translocation [3942]. Further, the microinjection of a constitutively active form of Ras activates glucose transport in cardiac myocytes [43] and the overexpression of activated Ras mimicks insulin action in 3T3-L1 adipocytes [44]. By contrast, in another study, the same last approach gave opposite results [45], and thrombin, epidermal growth factor and serum which also activate MAPK do not stimulate glucose transport [46-48]. A role for PI3-kinase in glucose transport is also strongly supported by the use of inhibitors such as wortmannin $[23,24,49]$ or LY294002 [50] which inhibit insulin-induced glucose transport stimulation. However, wortmannin would not only inhibit PI3-kinase as claimed previously but also MAPK $[51,52]$. To add to the confusion, it has been recently demonstrated that Ras could also regulate the activity of PI3-kinase by interacting with the catalytic subunit of the enzyme [53]. Overexpression of active Ras could thus activate PI3-kinase as well as MAPK. Finally, alterations in PI3-kinase activation and glucose transport stimulation have been observed in various insulin-resistant states $[20,54,55]$, but MAPK activation has not been measured in the same models. Further, the reduction in PI3-kinase activation seems to be more profound [20] and appears earlier [37] than the defect in glucose transport in insulinsensitive tissue of obese animals.

In conclusion, it appears that insulin resistance induced by chronic insulin treatment of 3T3-L1 adipocytes is associated with multiple defects, at the level of IRS 1, PI3-kinase and MAPK, and GLUT 4 translocation. Those defects are very similar to the altera- tions observed in hyperinsulinaemic states found in obese humans or rodents. This model will thus be very useful for a better understanding of the mechanisms of the alterations in the pathways leading from insulin receptor to GLUT 4 translocation.

Acknowledgements. This work was supported by grants from the Institut National de la Santé et de la Recherche Médicale (France), the University of Nice-Sophia Antipolis, and the Association pour la Recherche contre le Cancer (ARC No 2111). We thank Dr. M. Cormont for scientific discussion. We thank Dr. S.Giorgetti for antiphosphotyrosine antibodies, Dr. C.R.Kahn for the gift of anti-IRS-1 antibodies, and Dr. J.C.Scimeca and Dr. P.Peraldi for anti-MAPK antibodies. The illustration work of Mr G. Visciano is acknowledged.

\section{References}

1. Cushman SW, Wardzala LJ (1980) Potential mechanism of insulin action on glucose transport in the isolated rat adipose cell. Apparent translocation of intracellular transport systems to the plasma membrane. J Biol Chem 255: 47584762

2. Suzuki K, Kono T (1980) Evidence that insulin causes translocation of glucose transport activity to the plasma membrane from an intracellular storage site. Proc Natl Acad Sci USA 77: 2542-2545

3. Gould GW, Holman GD (1993) The glucose transporter family: structure, function and tissue-specific expression. Biochem J 295: 329-341

4. Sun XJ, Rothenberg P, Kahn CR et al. (1991) Structure of the insulin receptor substrate IRS-1 defines a unique signal transduction protein. Nature 352: 73-77

5. White MF, Kahn CR (1994) The insulin signaling system. J Biol Chem 269: 1-4

6. Skolnik EY, Batzer A, Li N et al. (1993) The function of GRB2 in linking the insulin receptor to Ras signaling pathways. Science 260: 1953-1955

7. Baltensperger K, Kozma LM, Cherniack AD et al. (1993) Binding of the ras activator Son of Sevenless to insulin receptor substrate-1 signaling complexes. Science 260: 19501952

8. Sun XJ, Miralpeix M, Myers MG Jr et al. (1992) Expression and function of IRS-1 in insulin signal transmission. J Biol Chem 267: 22662-22672

9. Waters SB, Yamauchi K, Pessin JE (1993) Functional expression of insulin receptor substrate- 1 is required for insulin-stimulated mitogenic signaling. J Biol Chem 268: 22231-22234

10. Tanti J-F, Grémeaux T, Van Obberghen E, Le MarchandBrustel Y (1994) Serine/threonine phosphorylation of insulin receptor substrate 1 modulates insulin receptor signaling. J Biol Chem 269: 6054-6057

11. Kahn BB (1992) Facilitative glucose transporters: regulatory mechanisms and dysregulation in diabetes. J Clin Invest $89: 1367-1374$

12. Kozka IJ, Clark AE, Holman GD (1991) Chronic treatment with insulin selectively down-regulates cell-surface GLUT 4 glucose transporters in 3T3-L1 adipocytes. J Biol Chem 266: 11726-11731

13. Rice KM, Lienhard GE, Garner CW (1992) Regulation of the expression of pp 160, a putative insulin receptor signal protein, by insulin, dexamethasone, and 1-methyl-3-isobutylxanthine in 3T3-L1 adipocytes. J Biol Chem 267: 1016310167 
14. Rice KM, Turnbow MA, Garner CW (1993) Insulin stimulates the degradation of IRS-1 in 3T3-L1 adipocytes. Biochem Biophys Res Commun 190: 961-967

15. Le Marchand-Brustel Y, Olichon-Berthe C, Grémeaux T, Tanti JF, Rochet N, Van Obberghen E (1990) Glucose transporter in insulin sensitive tissues of lean and obese mice. Effect of the thermogenic agent BRL 26830A. Endocrinology 127: 2687-2695

16. Giorgino F, Chen JH, Smith RJ (1992) Changes in tyrosine phosphorylation of insulin receptors and a 170,000 molecular weight nonreceptor protein in vivo in skeletal muscle of streptozotocin-induced diabetic rats: effects of insulin and glucose. Endocrinology 130: 1433-1444

17. Scimeca J.C, Ballotti R, Nguyen TT, Filloux C, Van Obberghen $\mathrm{E}$ (1991) Tyrosine and threonine phosphorylation of an immunoaffinity-purified 44-kDa MAP kinase. Biochemistry 30: 9313-9319

18. Student AK, Hsu RY, Lane MD (1980) Induction of fatty acid synthetase synthesis in differentiating 3T3-L1 preadipocytes. J Biol Chem 255: 4745-4750

19. Laemmli UK (1970) Cleavage of structural proteins during the assembly of the head of bacteriophage T4. Nature 227: 680-685

20. Heydrick SJ, Jullien D, Gautier N et al. (1993) Defect in skeletal muscle phosphatidylinositol-3-kinase in obese insulin-resistant mice. J Clin Invest 91: 1358-1366

21. Giorgetti S, Ballotti R, Kowalski-Chauvel A, Cormont M, Van Obberghen E (1992) Insulin stimulates phosphatidylinositol-3-kinase activity in rat adipocytes. Eur J Biochem 207: 599-606

22. Sun H, Charles CH, Lau LF, Tonks NK (1993) MKP-1 (3CH134), an immediate early gene product, as a dual specificity phosphatase that dephosphorylated MAP kinase in vivo. Cell 75: 487-493

23. Okada T, Kawano Y, Sakakibara T, Hazeki O, Ui M (1994) Essential role of phosphatidylinositol 3-kinase in insulininduced glucose transport and antilipolysis in rat adipocytes. Studies with a selective inhibitor wortmannin. J Biol Chem 269: 3568-3573

24. Clarke JF, Young PW, Yonezawa K, Kasuga M, Holman GD (1994) Inhibition of the translocation of GLUT1 and GLUT4 in 3T3-L1 cells by the phosphatidylinositol 3-kinase inhibitor, wortmannin. Biochem J 300: 631-635

25. Tordjman KM, Leingang KA, James DE, Mueckler MM (1989) Differential regulation of two distinct glucose transporter species expressed in 3T3-L1 adipocytes: effect of chronic insulin and tolbutamide treatment. Proc Natl Acad Sci USA 86: 7761-7765

26. Rosen OM, Smith CJ, Fung C, Rubins CS (1978) Development of hormone receptors and hormone responsiveness in vitro. Effect of prolonged insulin treatment on hexose uptake in 3T3-L1 adipocytes. J Biol Chem 253: 7579-7583

27. Flores-Riveros JR, McLenithan JC, Ezaki O, Lane MD (1993) Insulin down-regulates expression of the insulin-responsive glucose transporter (GLUT4) gene: effects on transcription and mRNA turnover. Proc Natl Acad Sci USA 90: 512-516

28. Clancy BM, Czech MP (1990) Hexose transport stimulation and membrane redistribution of glucose transporter isoforms in response to cholera toxin, dibutyryl cyclic AMP, and insulin in 3T3-L1 adipocytes. J Biol Chem 265: 12434-12443

29. Dhand R, Hiles I, Panayotou G et al. (1994) PI3-kinase is a dual specificity enzyme: autoregulation by an intrinsic protein-serine kinase activity. EMBO J 13: 522-533

30. Tanti J-F, Grémeaux T, Van Obberghen E, Le MarchandBrustel Y (1994) Insulin receptor substrate 1 is phos- phorylated by the serine kinase activity of phosphatidylinositol 3-kinase. Biochem J 304: 17-21

31. Lam K, Carpenter CL, Ruderman NB, Friel JC, Kelly KL (1994) The phosphatidylinositol 3-kinase serine kinase phosphorylates IRS-1. Stimulation by insulin and inhibition by wortmannin. J Biol Chem 269: 20648-20652

32. Giorgetti S, Ballotti R, Kowalski-Chauvel A, Tartare S, Van Obberghen E (1993) The insulin and insulin-like growth factor-I receptor substrate IRS-1 associates with and activates phosphatidylinositol 3-kinase in vitro. J Biol Chem 268: 7358-7364

33. Backer JM, Myers MG Jr, Sun X et al. (1993) Association of IRS-1 with the insulin receptor and the phosphatidylinositol $3^{\prime}$-kinase. Formation of binary and ternary signaling complexes in intact cells. J Biol Chem 268: 8204-8212

34. Skolnik EY, Lee C, Batzer A et al. (1993) The SH2/SH3 domain-containing protein GRB2 interacts with the tyrosinephosphorylated IRS1 and Shc: implications for insulin control of ras signalling. EMBO J 12: 1929-1936

35. Pronk GJ, De Vries-Smits AMM, Buday L et al. (1994) Involvement of Shc in insulin- and Epidermal Growth Factor-induced activation of p21 ${ }^{\text {ras }}$. Mol Cell Biol 14: 15751581

36. Sasaoka T, Draznin B, Leitner JW, Langlois WJ, Olefsky JM (1994) Shc is the predominant signaling molecule coupling insulin receptors to activation of guanine nucleotide releasing factor and $\mathrm{p} 21^{\text {ras }}-\mathrm{GTP}$ formation. J Biol Chem 269: $10734-10738$

37. Heydrick S, Gautier N, Olichon-Berthe C, Van Obberghen E, Le Marchand-Brustel Y (1995) Early alteration of insulin stimulation of PI-3 kinase in muscle and adipocyte from gold thioglucose obese mice. Am J Physiol 268: E604-E612

38. Saad MJA, Araki E, Miralpeix M, Rothenberg PL, White MF, Kahn CR (1992) Regulation of Insulin Receptor Substrate-1 in liver and muscle of animal models of insulin resistance. J Clin Invest 90: 1839-1849

39. Haystead TAJ, Weiel JE, Lichtfield DW, Tsukitani Y, Fischer EH, Krebs EG (1990) Okadaic acid mimics the action of insulin in stimulating protein kinase activity in isolated adipocytes. The role of protein phosphatase $2 \mathrm{~A}$ in attenuation of the signal. J Biol Chem 265: 16571-16580

40. Jullien D, Tanti J-F, Heydrick SJ et al. (1993) Differential effects of okadaic acid on insulin-stimulated glucose and amino acid uptake and phosphatidylinositol-3-kinase activity. J Biol Chem 268: 15246-15251

41. Lawrence JC Jr, Hiken JF, James DE (1990) Stimulation of glucose transport and glucose transporter phosphorylation by okadaic acid in rat adipocytes. J Biol Chem 265: 19768 19776

42. Tanti J-F, Grémeaux T, Cormont M, Van Obberghen E, Le Marchand-Brustel Y (1993) Okadaic acid stimulates IGF-II receptor translocation and inhibits insulin action in adipocytes. Am J Physiol 264: E868-E873

43. Manchester J, Kong X, Lowry OH, Lawrence JC Jr (1994) Ras signaling in the activation of glucose transport by insulin. Proc Natl Acad Sci USA 91: 4644-4648

44. Kozma L, Baltensperger K, Klarlund J, Porras A, Santos E (1993) The Ras signaling pathway mimics insulin action on glucose transporter translocation. Proc Natl Acad Sci USA 90: 4460-4464

45. Hausdorff SF, Frangioni JV, Birnbaum MJ (1994) Role of p21 ${ }^{\text {ras }}$ in insulin-stimulated glucose transport in 3T3-L1 adipocytes. J Biol Chem 269: 21391-21394

46. Robinson LJ, Razzack ZF, Lawrence JC Jr, James DE (1993) Mitogen-activated protein kinase activation is not sufficient for stimulation of glucose transport or glycogen 
synthase in 3T3-L1 adipocytes. J Biol Chem 268: 2642226427

47. Fingar DC, Birnbaum MJ (1994) Characterization of the mitogen-activated protein kinase/90-kilodalton ribosomal protein S6 kinase signaling pathway in 3T3-L1 adipocytes and its role in insulin-stimulated glucose transport. Endocrinology 134: 728-735

48. Van Den Berghe N, Ouwens DM, Maassen JA, Van Mackelenbergh MGH, Sips HCM, Krans HMJ (1994) Activation of the Ras/mitogen-activated protein kinase signaling pathway alone is not sufficient to induce glucose uptake in 3T3-L1 adipocytes. Mol Cell Biol 14: 2372-2377

49. Kanai F, Ito K, Todaka M et al. (1993) Insulin-stimulated Glut4 translocation is relevant to the phosphorylation of IRS- 1 and the activity of PI3-kinase. Biochem Biophys Res Commun 195: 762-768

50. Cheatham B, Vlahos CJ, Cheatham L, Wang L, Blenis J, Kahn CR (1994) Phosphatidylinositol 3-kinase activation is required for insulin stimulation of pp70 S6 kinase, DNA synthesis, and glucose transporter translocation. Mol Cell Biol 14: 4902-4911

51. Cross DAE, Alessi DR, Vandenheede JR, McDowell HE, Hundal HS, Cohen P (1994) The inhibition of glycogen syn- thase kinase- 3 by insulin or insulin-like growth factor 1 in the rat skeletal muscle cell line L6 is blocked by wortmannin, but not by rapamycin: evidence that wortmannin blocks activation of the mitogen-activated protein kinase pathway in L6 cells between Ras and Raf. Biochem J 303: 21-26

52. Welsh GI, Foulstone EJ, Young SW, Tavaré JM, Proud CG (1994) Wortmannin inhibits the effects of insulin and serum on the activities of glycogen synthase kinase- 3 and mitogen-activated protein kinase. Biochem J 303: 15-20

53. Rodriguez-Viciana P, Warne PH, Dhand R et al. (1994) Phosphatidylinositol-3-OH kinase as a direct target of Ras. Nature 370: 527-532

54. Giorgino F, Almahfouz A, Goodyear LJ, Smith RJ (1993) Glucocorticoid regulation of insulin receptor and substrate IRS-1 tyrosine phosphorylation in rat skeletal muscle in vivo. J Clin Invest 91: 2020-2030

55. Folli F, Saad MJA, Backer JM, Kahn CR (1993) Regulation of phosphatidylinositol 3-kinase activity in liver and muscle of animal models of insulin-resistant and insulin-deficient diabetes mellitus. J Clin Invest 92: 1787-1794 